workers' objections to protective policies in American industries during World War Two. Arwen Mohun (University of Delaware) addressed the provocative question of why workers sometimes willingly risked their health, discussing the "calculus of risk" as a social construct shaped by both labor and capital. Patricia Reeve (Boston College) waded in deep theoretical waters, illustrating the "construction of workers' bodies" in nineteenthcentury labor law. Jamie Bronstein (New Mexico State University) compared workers' accounts of accidents with those in the mainstream press: Were injured workers heroes-or victims? Unfortunate-or punished sinners? Illustrations of a Victorian fascination with bloody bodies sparked a comment by Mark Aldrich (Smith College) that the "deconstruction of workers' bodies" has a rather literal meaning in these contexts.

Gerald Markowitz (Graduate Center, City University of New York) and David Rosner (Columbia University School of Public Health) reminded workshop participants that much work remains for those who would challenge business definitions of health and obfuscation of industrial and environmental disease. Updating their work on silicosis, a "disease of the past" according to the professional and business community, they demonstrated that silicosis never vanished and is still claiming lives. New clusters of silicosis have arisen among America's most unorganized and disenfranchised workers in shipyards and refineries in Louisiana, Mississippi, and Texas-revelations that angered workshop participants. The workshops deepened participants' understanding of how business interests control disease definition and health ideologies on "both sides of the factory wall." And yet participants also learned about moments when that domination, while successful, has been at least temporarily challenged. In many panels and workshops, presenters and members of the audience alike agreed that the power of cross-class organizing in the past suggests strategies for workers and citizens today.

\title{
Boys and Their Toys? Masculinity, Technology, and Work
}

\section{Roger Horowitz}

Hagley Museum and Library

In October 1997, a lively audience of one hundred people gathered at the Hagley Museum and Library to hear papers related to the theme, "Boys and Their Toys? Masculinity, Technology, and Work." The conference emerged out of Hagley's ongoing efforts to encourage scholars engaged in innovative research on gender and society to make use of our printed and manuscript collections on business, work, and technology. 
Several papers on male workers drew creatively from the research of scholars such as Wayne Lewchuck, Joshua Freeman, Ava Baron, and Lisa Fine to discuss the fashioning and refashioning of working-class masculinity in the era of mass production. Scholars like Lewchuck have shown that the deskilling of work on the assembly line undermined the "respectable" manliness of the skilled craftsman at the same time that mechanization rendered unnecessary the strength and brawn exercised by the unskilled which had legitimated their "rough" version of working-class masculinity. The paper by Steven Meyer (University of Wisconsin, Parkside) showed how changes in work under Fordist production methods prompted a merger between "rough" and "respectable" forms of masculinity among automobile workers. Basing his paper on a close reading of shop-floor grievances, Meyer showed how affirmations of masculine autonomy and prerogatives informed conflicts between workers and supervisors and shaped local unions' efforts to control the workplace environment.

The tension between rough and respectable masculinity emerged in other papers. Nancy Quam-Wickham's essay on western US extraction workers showed how their physically taxing jobs stimulated an ethos which celebrated endurance, skill, and strength in performing required tasks. Creatively drawing on folklore as well as workaday practices, Quam-Wickham (California State University, Long Beach) discussed how working-class narratives of Paul Bunyan skewered him as an inept, muscle-bound bungler rather than as a paragon of the entrepreneurial western workers. A paper by Gregory Clancy (Massachusetts Institute of Technology) drew on the tension between the conception and the construction of buildings that fed the rivalries between architects and carpenters. Architects attempted to elevate their profession by distinguishing their conceptual mastery of building structures from the rough empirical knowledge of carpenters. In response, carpenters defended practical skills acquired through apprenticeship and work experience and ridiculed architects for developing flawed designs which had to be brought into conformity with the physical requirements of construction materials by experienced workers.

While still preeminently concerned with work, several papers located the formation and reformulation of working-class masculinity within larger cultural contexts. An imaginative paper by Ben Shackleford (Georgia Institute of Technology) on North American Stock Car (NASCAR) races and the pit-stop ritual showed how masculine labor in this setting was embedded in the technologically sublime spectacle of auto racing, as communicated to an audience through television. With technological competition among race cars limited by rules restricting modifications to the vehicle, the pit stop became the site of efforts to reorganize work and introduce machinery to increase efficiency and improve a car's competitive position. A paper by Jeffrey Suzik (Carnegie Mellon University) showed how the Civilian Conservation Corps's (CCC's) program for "building better men" emerged out of widespread public worries about unemployed teenagers 
and their inability to become true men during the Great Depression. Concern over instilling work discipline and strengthening the male body imbued CCC camps with a masculinizing zeal. Suzik drew on letters from young CCC workers to show how these men celebrated their physical attainments as well as the male bonding forged through the quasi-military organization of the camps and their workers' carousing in nearby towns. Christopher McKenna (Wharton School, University of Pennsylvania) continued the thematic concern with the male body by discussing how fatal workplace poisoning at DuPont factories in the 1920s demasculinized male workers. Unlike the NASCAR pit workers, whose masculinity was embedded in their skill and courageous encounter with danger, DuPont chemical workers could not confront the insidious and invisible threat posed by poisons on the job.

A series of papers on middle-class masculinity foregrounded popular culture by discussing how basic ethics of work changed in the early twentieth century because of the growth of entertainment industries and new forms of leisure. While Lewchuck's work informed the papers on workingclass masculinity, these essays drew more heavily on Michael Kimmel's notion of "consuming manhood," the manner in which the realm of consumption became an arena for asserting masculinity. The paper by Woody Register (University of the South) elaborated how early twentieth-century entertainment entrepreneurs played a pivotal role in redefining playfulness and leisure as legitimate masculine pursuits. Whether building theme parks, performing in the theater, or designing museums, these men aimed to blur the line between boyhood and manhood by allowing grown men to celebrate and enjoy whimsy and play. The contemporary respect accorded these "Everyday Peter Pans" (as Register titled his paper) reflected deep shifts in enviable gender models for successful men which would reach fruition in the postwar celebration of entertainment impresarios like Steven Spielberg and Ted Turner.

While Register showed how playful forms of work could be masculine, Steven Gelber (Santa Clara University) inverted this approach by showing how devotion to home improvements, that is, turning leisure into work, could serve as a manly badge for mid-twentieth-century middle-class men. While men of this class in the nineteenth century would have hired skilled tradesmen for even simple household improvements (like hanging a picture), they began drawing on a new generation of power tools in the 1930s and the postwar period to engage in major modifications of their own dwellings. Gary Cross (Pennsylvania State University) brought the conference full circle by discussing the changes in toys for boys in the first three decades of the twentieth century. Practical technological toys characteristic of the early century were designed to acquaint boys with machinery and business methods and to prepare them for successful careers. During the Depression these practical toys were displaced by spaceships, Buck Rogers figures, and other predecessors of contemporary "action figures" that cele- 
brated fantasy and severed boyhood games from the "real" world of adulthood.

Comments by Joshua Freeman (Queens College, City University of New York) on one panel raised questions that went beyond the particular papers in his session and stimulated a great deal of side discussion among those in attendance. While praising the fresh research and high quality of the papers, Freeman noted the virtual absence of women and families from these discussions of masculinity. He raised a cautionary note-that new interest in men's studies should not result in ignoring the importance of women in the development of masculine identities. Gender, he reminded the audience, is rooted in relationships not only among men but between men and women. In a related vein, he asked that the authors consider more fully the issue of sexuality in the construction of masculinity and how the images and language referred to in the papers often also contained sexual and autoerotic overtones.

Those intrigued by these thoughtful papers will be able to read revised versions of some of them in a 1999 issue of Men and Masculinities, a journal edited by Michael Kimmel. Other papers will doubtless emerge in other venues. The conference showed, above all, that attention to masculinity, work, and technology is a fresh area of research in which much promising work is being done-and still needs to be done.

\title{
In Search of a Lost Working Class: Workers in the Soviet
}

Occupation Zone/German Democratic Republic, 1945-1970

\section{Anna-Sabine Ernst and Gerwin Klinger}

Freelance Journalists, Berlin

\section{Annette Timm}

University of British Columbia

\begin{abstract}
What became of the working class in the German "workers' and peasants' state"? What possibilities did workers have to represent their interests in conflicts with their supposed avant-garde, the Communist party (CP)? What happened to the traditional worker milieus? Did they lose their unique contours and disappear into a kind of homogenized society of working people, or did the proletarian habitus itself determine the style of the new society? These questions still await answers, since "workers in the German Democratic Republic (GDR)" still describes a blank area on the map of social historical research. At first glance this may seem astound-
\end{abstract}

